\title{
An Informal Science Educator/Elementary School Teacher Collaboration: Changing Fifth Grade Girls' Perceptions of Scientists and Engineers
}

\author{
Florence F. McCann'1, Edmund A. Marek1, Carell Falsarella ${ }^{2}$ \\ ${ }^{1}$ Instructional Leadership and Academic Curriculum, Jeannine Rainbolt College of Education, University of Oklahoma, Norman, OK, \\ USA \\ ${ }^{2}$ Norman Public Schools, Norman, OK, USA \\ Email: fmccann@sbcglobal.net, eamarek@ou.edu
}

How to cite this paper: McCann, F. F., Marek, E. A., \& Falsarella, C. (2016) An Informal Science Educator/Elementary School Teacher Collaboration: Changing Fifth Grade Girls' Perceptions of Scientists and Engineers. Creative Education, 7, 2459-2475. http://dx.doi.org/10.4236/ce.2016.716234

Received: September 24, 2016

Accepted: October 172016

Published: October 20, 2016

Copyright $\odot 2016$ by authors and Scientific Research Publishing Inc. This work is licensed under the Creative Commons Attribution International License (CC BY 4.0).

http://creativecommons.org/licenses/by/4.0/

(c) (i) Open Access

\begin{abstract}
This study examined how an informal science educator-elementary school teacher partnership based on a coordination relationship (Weiland \& Akerson, 2013) operated in the development and implementation of a STEM (Science, Technology, Engineering and Mathematics) Club for girls. A case study methodology was used to understand how the informal science educator-elementary school teacher partnership functioned in the context of the STEM Club. Images of scientists and engineers drawn by the girls before and after participation in the STEM Club were written artifacts used to assess the girls' perceptions of scientists and engineers. The girls maintained the traditional images of scientists that they brought to the Club, modified, however, to include more female images after participation in STEM Club. The girls' perceptions of engineers changed dramatically from non-existent or mechanics/ repairmen to realistic images of engineers, including female images, involved in design, laboratory investigation and testing activities. The percentage of female images drawn by the girls increased by $30 \%$ and $42 \%$ for scientist images and engineer images, respectively.
\end{abstract}

\section{Keywords}

Educator Partnerships, Engineer Stereotypes, Gender Issues, Gifted Education, Scientist Stereotypes

\section{Introduction}

The stereotypical image of the scientist as white and male remains largely unaltered 
over the past fifty years. Despite efforts by educators and the STEM (Science, Technology, Engineering and Mathematics) community to change girls' identities in science (Scantlebury, Tal, \& Rahm, 2007) and to increase participation of females and ethnic minorities in STEM careers, the STEM workforce likewise remains predominantly white and male (Rawson \& McCool, 2014). Women and ethnic minorities have been marginalized and their contributions undervalued by the STEM community (TuckerRaymond, Varelas, Pappas, Korzh, \& Wentland, 2007).

Children's images of scientists become fully developed and stable between the $3^{\text {rd }}$ and $5^{\text {th }}$ grades (Chambers, 1983). A recent study by Walls (2012) of African-American $3^{\text {rd }}$ graders validated this 30 year old finding that children formulate their views of scientists by the lower elementary school grades. Joyce and Farenga (1999) concluded that high ability children have decided whether they will study science by age 9 . Maltese \& Tai (2010) studied a group of scientists and found that these scientists developed their interest in science before middle school. Silver \& Rushton (2008b) concluded that it is "children's stereotypical images of scientists, rather than an actual dislike of science and design technology that dissuades them from becoming scientists and engineers" (Silver \& Rushton, 2008b: p. 66). They identified a "need to provide more positive, inspiring images of the work of scientists and engineers if children are to be encouraged to consider these career options" (Silver \& Rushton, 2008b: p. 66).

Girls' attrition from science begins between the ages of 9 and 14 starting with entry into upper elementary school grades (Steinke \& Long, 1996). Children need "to tie the word scientist to a particular person" (Ashbrook, 2010: p. 26). Teen girls need that "particular person" to be female. Female mentors encourage persistence in STEM (National Science Teachers Association [NSTA], 2011a, 2011b; Vanmali \& Abell, 2009) and are "effective and important in improving self-efficacy" (Bohrmann \& Akerson, 2001: p. 51).

Programs that bring scientists and/or engineers into elementary school classrooms have had mixed results in changing elementary school students' perceptions of scientists. The Horsham Greenpower Goblin Challenge (HGGC) in the UK (Silver \& Rushton, 2008a; Silver \& Rushton, 2008b) was a project-based program that involved $9-11$ year olds in building and racing a single-seat electric car. Children built the cars as a class during a 1 - 2 week period, typically during school hours. Adults assisted and a female engineer provided technical expertise and final safety inspections. After participation in HGGC, students drew images of scientists that were more stereotypical than the scientist images they had drawn prior to participation. Likewise, their engineer images showed more repairing activities and car mechanic stereotypes.

In other interventions at the elementary school level, scientists and engineers visited formal science classes during the school day. A visit by a female STEM practitioner resulted in more girls drawing female scientist images after the visit than did a visit by a male STEM practitioner (Bodzin \& Gehringer, 2001: p. 38). However, another study (Buck, Leslie-Pelecky, \& Kirby, 2002) demonstrated persistence of stereotypical scientist images even when three young female scientists worked with $4^{\text {th }}$ and $5^{\text {th }}$ graders in 
their elementary school classrooms on a daily basis over a four week period. While in the classrooms, these scientists led physical science inquiry activities and discussed their research careers with the children. The students actually "questioned the true identity of the scientists, categorizing them as teachers" (Buck et al., 2002: p. 1). By contrast, an after-school, museum sponsored informal science education program enhanced gifted $4^{\text {th }}$ and $5^{\text {th }}$ grade students' understanding of scientists' work and increased their interest in science careers (Melber, 2003).

In all of the foregoing studies, the scientists or engineers were strictly visitors. There was no indication that any type of relationship was established between them and the classroom teachers whose rooms they visited. Weiland \& Akerson (2013) showed that fifth grade students gained content knowledge from a life science lesson prepared and implemented as a result of an informal educator and elementary school teacher partnership. They explored this relationship using a case study methodology and examined the roles that each educator played in the partnership. The informal educator provided "expertise and resources not readily available to them" (Weiland \& Akerson, 2013: p. 1333). The elementary school teacher's role included "classroom management, making connections to classroom activities and curricula and clarifying concepts" (Weiland \& Akerson, 2013: p. 1333). Significantly, the two educators, the informal science educator and the elementary school teacher, felt that these roles were "critical to the optimization of the short time frames $(1 \mathrm{~h})$ the informal educator was in the classroom" (Weiland \& Akerson, 2013: p. 1333).

There is a clear need for informal STEM education opportunities for girls between the ages of 9 and 14 that can provide authentic images of STEM practitioners, including scientists and engineers. Elementary school age children, including children identified as gifted, can engage in scientific inquiry (McNeill, 2011) and develop more sophisticated understandings of scientists' works. The specific nature of the intervention is an important factor in determining whether and how children's, especially girls', perceptions of scientists and engineers can be influenced. An interactive partnership between an informal science educator (ISE) and an elementary school teacher (EST) such as the relationship of "coordination" described by Weiland \& Akerson (2013, pp. 1336-1337) holds promise for development and implementation of an informal science education program for girls, a STEM Club. The STEM Club must preserve the scientist/engineer's identity with regular, but not daily, interactions with the girls. It must provide high quality inquiry STEM learning experiences in the informal learning environment that can be created through collaboration of an informal science educator and an elementary school educator.

\section{Research Design}

\subsection{Research Questions}

There were two research questions for the study:

1) How can a partnership built on a coordination relationship between a female informal science educator and a female elementary school teacher as defined by Weiland 
\& Akerson (2013) operate in the development and implementation of a STEM Club for gifted fifth grade girls?

2) How does participation in such a STEM Club affect gifted fifth grade girls' perceptions of scientists and engineers?

The purpose of this study was two-fold. First, to examine how a partnership built on a coordination relationship between a female informal science educator and a female elementary school teacher could develop and implement an informal science education program, a STEM Club for gifted fifth grade girls, in an elementary school setting. Secondly, the research addressed how participation in a STEM Club affected gifted fifth grade girls' perceptions of practitioners of science and engineering, scientists and engineers. The girls' perceptions of practitioners of technology and mathematics, "technologists" and mathematicians, respectively, were not considered. For the purposes of this paper, scientists are defined as practitioners of the natural sciences including "school science" (Schibeci, 1986: p. 139), i.e., "the natural sciences (physical and biological) sciences with the addition of earth science". Engineers are defined as practitioners of civil, environmental, aerospace, mechanical, structural, chemical, materials, electrical, computer or petroleum engineering.

\subsection{Method}

Following the approach taken by Weiland \& Akerson (2013), the present study used a case study approach to explore how the informal science educator-elementary school teacher partnership and the gifted fifth grade girls interacted in the classroom based STEM Club. Fifth grade girls were chosen because girls' attrition from science begins between the ages of 9 and 14 starting with entry into upper elementary school grades (Steinke \& Long, 1996). The unit of analysis for the study (Patton, 2002) was the informal science educator/elementary school teacher partnership and the gifted fifth grade girl STEM Club participants. The study was approved by the University of Oklahoma Institutional Review Board.

\subsection{Participants}

\subsubsection{The Informal Science Educator}

The informal science educator (ISE) was one of the co-authors, Florence McCann, a European-American female. She was then a doctoral student in science education and had experience providing informal STEM education programs for elementary school age children for almost 10 years (McCann, Marek, Pedersen, \& Falsarella, 2007; McCann, Millsap, Schmidt, \& Falsarella, 2010; McCann, Pedersen, Falsarella, \& McCann, 2008) when this research was conducted. She had a bachelor's degree in physics and a master's degree in materials science and engineering and had published articles in peer reviewed journals in these STEM fields.

\subsubsection{The Elementary School Teacher}

The elementary school teacher (EST) was one of the co-authors, Carell Falsarella, also a European-American female. She was then the Gifted Resource Coordinator responsible 
for school wide and pull-out enrichment programs for grades pre-K-5 at a large suburban elementary school. She had bachelor's and master's degrees in education and over 40 years of combined experience as an elementary and middle school classroom teacher, reading specialist, and gifted resource coordinator. In addition to her science enrichment work with the ISE, she also had extensive experience organizing science and invention fairs.

\subsubsection{The Gifted Fifth Grade Girls-The STEM Club Members}

All identified gifted girls in the fifth grade were invited to join STEM Club. The selection criteria were that the girls be identified gifted fifth grade girls. The only demographic information collected was that the girls were identified as gifted and participated in the Norman Public Schools district gifted and talented program. Of the 12 girls who accepted the invitation, 8 gave their assent and had parental consent to participate in the current study. The remaining 4 girls, who were not part of the study, attended all STEM Club meetings and took part in all Club activities. However, their scientist and engineer drawings were returned to them and were not included as data for the present study. The EST advertised the Club to gifted female $5^{\text {th }}$ graders as well as to their parents and fifth grade teachers. She recruited Club members and study participants. She obtained all parental consents and children's assents for girls participating in the study. Only the EST knew the identities of the girls who were participating in the study. The ISE did not know the identities of study participants. The number of participants, 12, was adequate for the study, since the research design involved a case study approach.

\subsection{Data Sources}

Multiple forms of data were collected and analyzed according to a data triangulation method (Patton, 2002) as used by Weiland \& Akerson (2013). Primary data sources included both the ISE and EST co-authors' first-hand impressions of their planning sessions for STEM Club curriculum, and their observations during the monthly STEM Club meetings. Secondary sources were emails between the ISE and EST regarding the curriculum and organization for the monthly STEM Club meetings; notes from their meetings; lesson plans; notes and photos taken by the EST during STEM Club meetings; as well as pre- and post- STEM Club participation images of scientists and engineers drawn by the girls.

\section{Results}

\subsection{The STEM Club}

The STEM Club was an enrichment activity offered at a large (over 600 students), suburban elementary (grades pre-K-5) school in the Southwestern United States. Fewer than $40 \%$ of students at the school qualified for free or reduced-price lunch. The EST and the ISE led the Club. STEM Club met 7 times, approximately once monthly, for 40 minutes during the school day in the elementary school teacher's classroom.

The ISE and the EST identified three items as hallmarks of a successful STEM Club: 
1) learning STEM by doing, (2) making STEM learning fun, and (3) connecting STEM learning to real life experiences (NSTA, 2011a, 2011b; 2010). These criteria guided them in selection and design of the elementary school STEM Club activities. Since STEM Club members were identified gifted $5^{\text {th }}$ graders, the ISE and EST incorporated instructional strategies that addressed the particular needs of gifted STEM learners (Park \& Oliver, 2009) into each Club meeting. Activities were appropriately paced and challenging questions were welcomed. The ISE and EST encouraged risk taking to counter the perfectionism and fear of failure often experienced by gifted students, especially gifted girls (Park \& Oliver, 2009). They provided a psychologically safe environment where the girls could explore their STEM abilities and develop their STEM identities (Carlone, Hauen-Frank, \& Webb, 2011; O’Neill, 2010). Within this safe environment, the ISE and EST deliberately implemented strategies to improve the girls' STEM self-efficacy, including "specific praise" (Bohrmann \& Ackerson, 2001: p. 51). The ISE and EST consistently complimented the girls when they displayed scientific reasoning and practice skills in the context of independent decision-making. They referred to each girl as a "scientist" and/or "engineer".

During each STEM Club meeting, the girls collaborated in teams of four (NSTA, 2011a, 2011b; Vanmali \& Abell, 2009) on inquiry science investigations developed specifically for STEM Club by the ISE and EST. The EST informed the ISE about the science curriculum that the girls were learning in their formal science classes. The ISE then assumed primary responsibility for developing STEM Club investigations. She provided some equipment and materials. The EST obtained additional equipment and supplies.

These investigations used a two-pronged lesson model such as those found at www.lessonplanet.com. The ISE embedded two-pronged STEM Club lessons within a 5-E (engage, explore, explain, extend and evaluate) instructional approach (Marek, 2009). The first "prong" of the lesson was the STEM content. The second "prong" was a "life lesson" that suggested ways to use STEM understanding to be a responsible citizen (Hodson, 2004; 2003). The ISE designed the lessons to support the girls' science learning by encouraging them to be part of a solution to a STEM-related problem facing society (Vanmali \& Abell, 2009). Specifically, the unifying theme of these life lessons was "living green" by using STEM knowledge to be a more efficient energy consumer. The lessons also prompted the girls to be the inventors of the next generation of green energy solutions.

Prior to each STEM Club meeting, the EST reminded the girls and their teachers about the Club meeting in her classroom. She assigned the students to work together in groups of four that best accommodated the girls' individual work styles and dispositions. EST arranged tables and chairs in her classroom for each group based on her group assignments and set out supplies along with the girls' laboratory notebooks. The ISE arrived about an hour before each Club meeting. The ISE and EST discussed the agenda for the meeting and completed set up of materials and equipment.

The STEM-related life lesson was in the engage phase. During the explore phase, the 
girls collaborated in their groups to perform materials rich inquiry activities and collect data needed to develop the STEM concept. While the EST was primarily responsible for classroom management (Weiland \& Akerson, 2013), both the ISE and EST circulated among the groups during the explore phase. They encouraged the girls to analyze and interpret their data. The girls made entries in their STEM Club notebooks. The ISEhelped the girls use their laboratory notebooks to record data and document how their thinking and understanding had developed over the course of the school year (Leffler \& Crauder, 2011). During the explain phase, all Club members together developed the STEM concept.

In the extend phase, the girls revisited the life lesson first introduced in the engage phase and made connections to the STEM concept. The extend phase offered strategies for how the girls could use their STEM knowledge to "make a difference" (Kaufman, 2010). Life lessons were intended to go beyond a science-technology-society (STS) curriculum perspective. Rather, they were designed to help the girls become proactive in developing their own positions regarding responsible use of energy resources and then take action within their homes and families (Hodson, 2004; 2003).

The evaluate phase began at the end of each Club meeting when the girls classified that day's investigation as " $\mathrm{S}$ " for science, " $\mathrm{E}$ " for engineering, " $\mathrm{T}$ " for technology or "M" for mathematics. This was an opportunity for the girls to exercise their metacognitive skills as they reflected on their learning. Typically, there was lively discussion about how best to classify each investigation. The investigations deliberately integrated at least 3 and occasionally all 4 STEM disciplines. Debates indicated that the girls accurately perceived how the activities included content from multiple STEM disciplines. Most often, the girls concluded that there was some content from each STEM discipline, but that one discipline predominated.

In order to maintain a relaxed club atmosphere, the ISE and EST made informal assessments of the girls' learning during and after each Club meeting. These included formative assessments of the girls' understanding based on observations of group discussions and responses to questions during Club meetings. The girls' notebook entries were reviewed after each Club meeting by the ISE and EST to gain insight into the development of their STEM reasoning and grasp of STEM content (Carlisle, 2011). The EST kept the laboratory notebooks in her classroom.

\subsection{The Effect of STEM Club Participation on the Gifted Fifth Grade Girls' Perceptions of Scientists and Engineers}

In order to address the second research question, the fifth grade girls' perceptions of scientists and engineers were examined using three instruments: Draw-A-ScientistChecklist (DAST-C) (Finson, Beaver, \& Cramond, 1995); Enhanced-Draw-A-ScientistTest (E-DAST) (Farland-Smith \& McComas, 2009); and Draw-An-Engineer-Test (DAET) (Knight \& Cunningham, 2004; Thompson \& Lyons, 2008). The DAST and DAET were administered as pre-tests at the beginning of the first Club meeting in late fall and as post-tests at the beginning of the last Club meeting in late spring. Figures 1-6 show some of these drawing artifacts. The girls drew the images using pencils, re- 


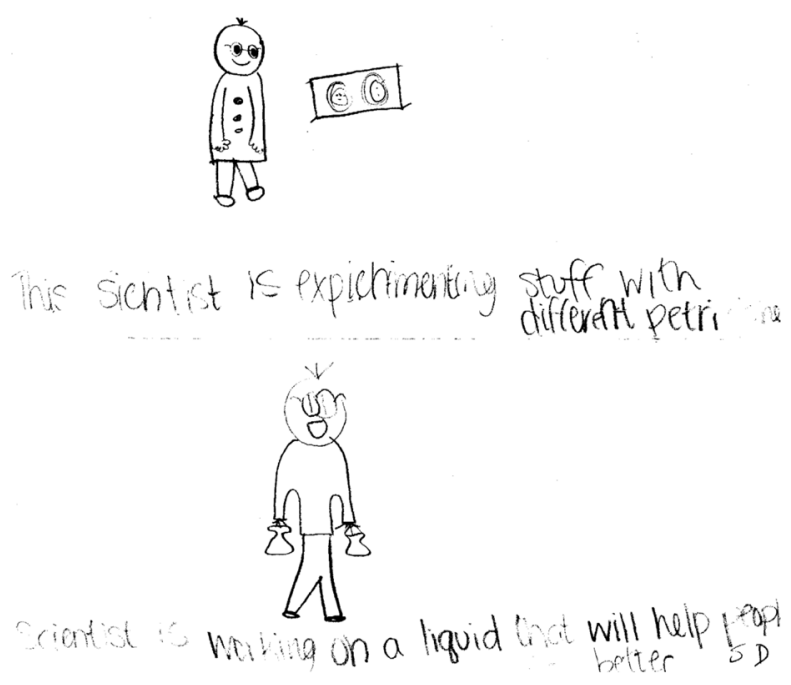

Figure 1. Male scientist images drawn by a girl on the DAST pre-test.<smiles>CC(C)(C)C(C)(C)C</smiles>
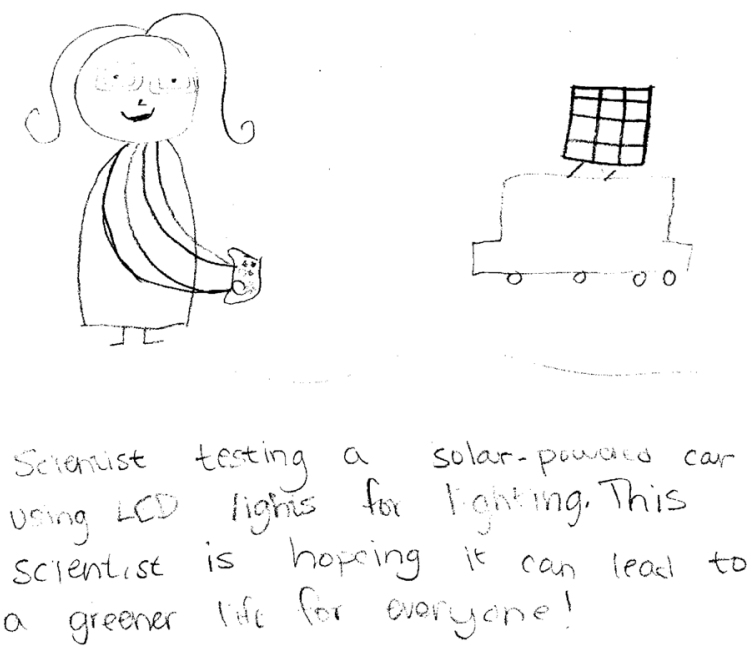

Figure 2. Female scientist DAST post-test image drawn by the same girl who drew the pre-test image shown in Figure 1.

sulting in faint lines and caption lettering. In order to preserve the integrity of these artifacts as expressions of the girls' perceptions, the drawings were scanned without any retouching or editing to make lines or letters more distinct.

Three raters working independently scored each pre- and post-test scientist drawing according to the DAST-C (Finson et al., 1995) and E-DAST (Farland-Smith \& McComas, 2009) evaluation criteria. The raters were the ISE, the EST and a professor of 


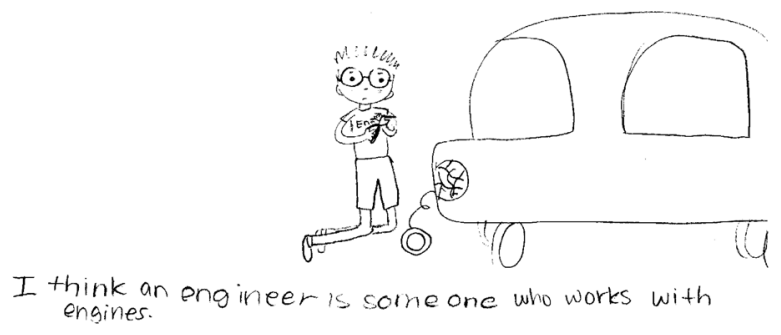

Figure 3. DAET pre-test drawing of a male figure holding a tool, presumably to repair a broken car light.

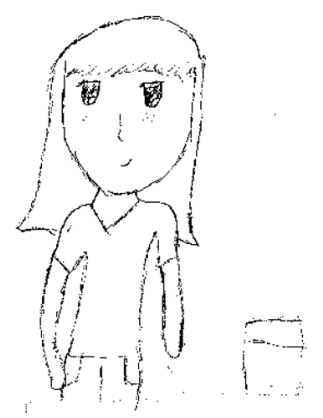

Figure 4. DAET post-test image of a female engineer doing laboratory work drawn by a girl who before attending STEM Club had no idea of what an engineer was or did.

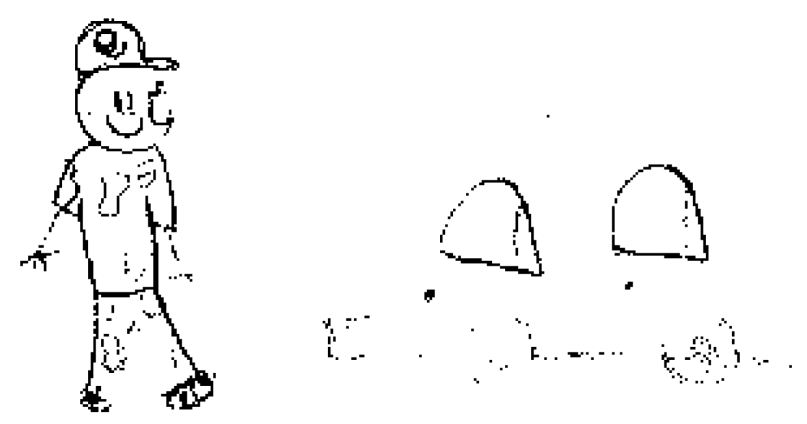

Figure 5. DAET pre-test drawing of a stereotypical male mechanic wearing dirt spattered clothing and standing beside a car.

science education, the third co-author. Descriptive statistics were calculated because 1) DAST-C and the E-DAST were written artifacts of the ISE/EST partnership (and resulting STEM Club) impact on the girls' perceptions of scientists and engineers and 2) the sample size, $\mathrm{n}$, was small. The mean pre-test score and the mean post-test score were compared as indicators of trends in the girls' perceptions.

The Draw-A-Scientist-Checklist was used to score the DAST-C. The Checklist in- 

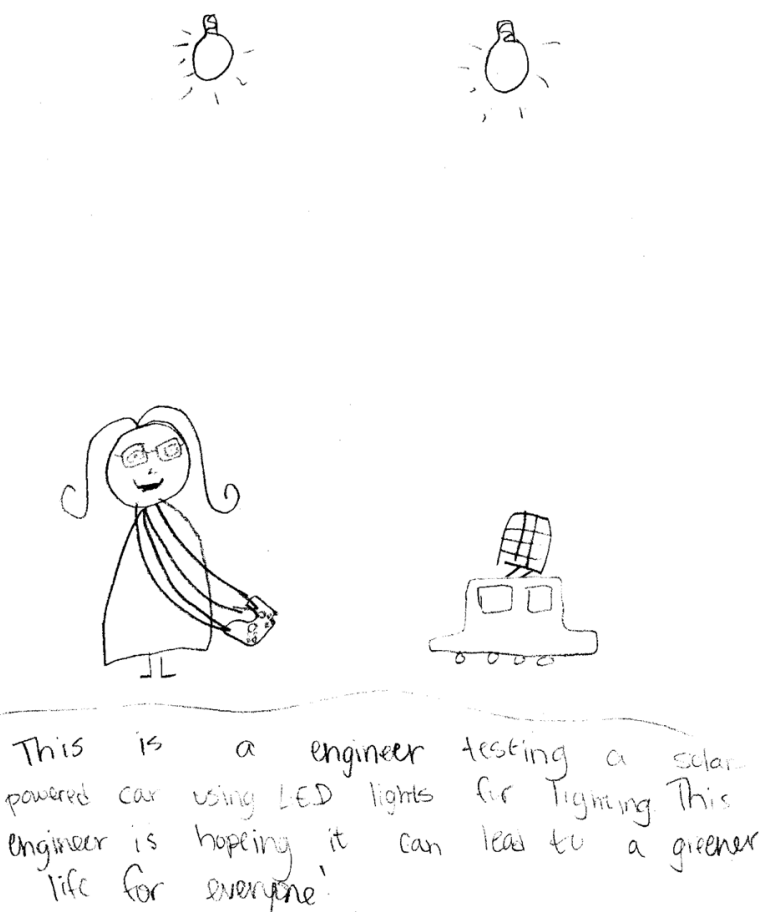

Figure 6. DAET post-test image drawn by the same girl who drew the male engineer image in Figure 5.

ventoried symbols in a drawing associated with a stereotypical image of a scientist that appears in a drawing. A high DAST-C score was associated with a stereotypical scientist image; a low score was associated with a realistic scientist image. DAST-C scores for 7 of the 8 girls either stayed the same or declined slightly after participation in STEMClub. These data indicated that most girls maintained the traditional (Chambers, 1983; Silver \& Rushton, 2008b), although not monstrous or cartoonish, scientist images that they brought to the Club or developed slightly more realistic scientist images. The appearance of the drawings corroborated the trend in the pre- and post-DAST-C scores.

The DAST Checklist analysis did not include gender. Hence, the DAST-C scores did not provide information on the gender of the scientist images shown in the drawings. However, portrayals of scientist gender in the drawings did change after the girls' participation in STEM Club. While only 1 of 8 pre-test DAST drawings showed an identifiably female scientist image, 3 of 7 post-test DAST drawings showed an identifiably female scientist image. This represented a change from 13\% female scientist images prior to STEM Club participation to $43 \%$ female images after participation in STEM Club. Drawings shown in Figure 1 and Figure 2 were representative of this change. The girls used pencil to make their drawings resulting in the faint lines in parts of the drawings. Furthermore, the female scientist image in Figure 2 and the female engineer image in Figure 6 showed a hairstyle and glasses that resembled the female ISE's hairstyle and glasses. Farland-Smith (2012) likewise found that $5^{\text {th }}-9^{\text {th }}$ grade girls, presumably representing a range of intellectual abilities, drew E-DAST scientist images that similarly included details of eyeglass and hair style. She concluded "that the scientists 
were not just viewed as teachers the girls had spent the day with, but had become real people to them (Farland-Smith, 2012: p. 15)".

The E-DAST scoring rubric enabled a more sophisticated interpretation of the DAST drawings by characterizing the scientist image according to the criteria of "Appearance", "Location" and "Activity". These criteria were scored as "Can't Be Categorized", "Sensationalized", "Traditional" or "Broader than Traditional" (Farland-Smith \& McComas, 2009: p. 50). The highest possible E-DAST score, 9, indicated a scientist image that transcended the traditional stereotypical appearance, location and activity, while lower scores were associated with stereotypical images.

For more than half of the girls, E-DAST scores increased after participation in STEM Club. Eighty-six percent of post-test scores were in the range of $7-9$, placing them solidly in the category of "Broader than Traditional" images. By comparison, $100 \%$ of pre-test scores were in the range of 5 - 7 indicating that students held "Traditional" scientist images when they began STEM Club. This trend in E-DAST scores was evidence that the gifted fifth grade girls' images of scientists had evolved from traditional, stereotypical images to more realistic images that went beyond the standard, stereotypical image.

The girls' drawings likewise corroborated that their scientist images after participation in STEM Club extended beyond the traditional, mostly male stereotype. The drawings showed change, not only in terms of including more depiction of female scientists, but in showing settings other than a laboratory.

Each pre and post-test DAET drawing was separately scored according to two rubrics, the Knight \& Cunningham (2004) image frequency analysis (Knight \& Cunningham, 2004) and the "DAET Scoring Guide" (Thompson \& Lyons, 2008: pp. 199-200). The ISE, EST, and the science education professor scored the DAET drawings independently.

The image frequency analysis (Knight \& Cunningham, 2004) identified and tallied the occurrence of traditional, stereotypical images associated with engineering in DAET drawings. This rubric designated 6 thematic groupings: 1) images of building/fixing, 2) images of designing, 3) images of products of mechanical engineering, 4) images of products of civil engineering, 5) images of trains, and 6) images of laboratory work. The pre-test drawing in Figure 3 linked the activity of fixing to a product of mechanical engineering, the car. Another drawing depicted building activity and incorporated traditional symbols associated with construction, a hard hat and a nail gun. However, the image went beyond the stereotypical construction/building image by showing a female construction worker. The girls did not draw any train-related images on the pre-test.

Comparison of pre- and post-test DAET image frequencies showed a decline in the presence of stereotypical images of products of mechanical engineering after participation in STEM Club. The decline from $50 \%$ to $29 \%$ in the images of products of mechanical engineering, i.e., engines and cars, was especially marked The ISE and EST raters sometimes recognized images in the girls' drawings of materials and equipment that they had worked with during Club meetings. They interpreted these image ele- 
ments as evidence that the girls had retained the science and engineering content from the STEM Club activities. Neither gender nor race/ethnicity was included in the Knight \& Cunningham (2004) image analysis rubric.

The evolution of the fifth grade girls' perception of engineers was evident in the images they drew on the DAET. Their post-test DAET images showed designing activity and laboratory work as aspects of engineering as well as female engineers. Girls' engineer images created after participating in STEM Club reflected a more realistic, sophisticated understanding of engineering. These post-test drawings replaced the fixing and building or creating products shown in the images drawn before participation in the Club with design and laboratory research activity. On the pre-test DAET, one girl was unable to draw an image of an engineer. Instead, she wrote, "Nothing in my mind ... what does an engineer do?" On her post-test DAET, she drew an image of a nonstereotypical, female engineer doing laboratory work is shown in Figure 4.

The DAET Scoring Guide (Thompson \& Lyons, 2008) was a tool for assessing the extent to which the image conveyed an accurate and complex understanding of engineering. The Guide scored drawings on a scale from 0-2 based on 4 categories: (1) "Engineering Artifacts (Tools/Equipment/Models/Symbols); (2) "Diversity of Fields"; (3) "Engineering Processes"; and (4) "Portrayals of Engineering" (Thompson \& Lyons, 2008). Overall scores obtained using the DAET Scoring Guide could range from 0-8 corresponding to levels of understanding of engineering from total ignorance about the field (0) to a highly nuanced understanding (8). The sophisticated understanding of engineering encompassed realistic design, experimentation and presentation of information.

Comparison of pre and post-test DAET Scoring Guide scores showed that for 7 of 8 girls, DAET scores increased after being a member of STEM Club. Pre- and post-test DAET drawings corroborated the trend in the DAET scores. One girl's engineer image developed from a traditional male auto mechanic standing near a car (Figure 5) to a female engineer performing laboratory testing on a model of a "green" car equipped with solar panels and LED lights (Figure 6). This girl's post-test engineer drawing was identical to her post-test scientist drawing, except for changing the word "scientist" to "engineer" in the caption of the engineer drawing. This similarity may have reflected her understanding of the inter-connected nature of the science and engineering STEM disciplines that was evident during Club discussions. Both post-test drawings also demonstrated this girl's retention and synthesis of science content and the life lesson she learned during STEM Club inquiry investigations.

\section{Conclusions}

This study, the ISE and EST, just as the informal science educator and the elementary school teacher, of the Weiland \& Akerson (2013) study, achieved a coordination relationship. Their nearly 10 years of working together to offer science enrichment programs provided them with the rapport and mutual respect that enabled them to undertake the project of developing a STEM Club for gifted fifth grade girls from literally "the 
ground up". The EST knew the needs and interests of the gifted fifth grade girls. She communicated them to the ISE and together they developed a curriculum that integrated science/engineering and social studies to engage the girls. Together, the ISE and EST monitored the girls' learning of science/engineering content knowledge through informal discussions and the written artifacts of the girls' lab notebooks. Drawing based instruments revealed that through the STEM Club, this synergistic partnership changed gifted fifth grade girls' perceptions of scientists and engineers.

Gifted fifth grade girls' DAST and DAET drawings provided insight into how their understandings of scientists and engineers changed over the course of 7 STEM Club meetings. The most dramatic change was observed in their perceptions of engineers. Images drawn before participation in STEM Club were highly stereotypical representations that associated engineers with repairmen, mechanics or construction workers, albeit a female construction worker for one girl. These pre-test images were consistent with the findings of Silver \& Rushton (2008b). Images drawn after STEM Club involvement replaced those traditional images with non-traditional images of females doing authentic design or laboratory work. One girl's perception moved from a completely naïve understanding of not knowing what an engineer was or did, to that of a non-stereotypical female engineer doing laboratory work as shown in Figure 4.

Changes in the girls' perceptions of scientists were more subtle. Their pre-STEM Club images of traditional, male scientists primarily doing bench chemistry work with beakers and flasks were broadened to less traditional images that included female scientists or scientists engaged in teaching. However, some traditional images did persist even after participation in STEM Club. These results were consistent with Melber's (2003) findings that gifted fourth and fifth graders drew DAST images with fewer stereotypical elements after participating in a museum after-school outreach program.

These gifted fifth grade girls already had fairly well established perceptions of scientists as reflected in the images of scientists that they drew. These findings were consistent with those of Chambers (1983) who showed that children's scientist images stabilized between the $4^{\text {th }}$ and $5^{\text {th }}$ grades. Participation in a STEM Club with a female scientist/engineer ISE was successful in modifying these images to be somewhat less traditional, particularly with respect to scientist gender. Drawings made after STEM Club participation showed a $30 \%$ increase in the number of female scientist images. This increase in the number of female scientist images was consistent with the findings of Bodzin \& Gehringer (2001). Their study found that $4^{\text {th }}$ and $5^{\text {th }}$ grade students visited by a female STEM practitioner drew more female scientist images than students in the classroom visited by a male STEM practitioner.

Gifted fifth grade girls' perceptions of engineers were more plastic than their perceptions of scientists. At the outset, the girls confused engineers with technicians and repairmen. They held stereotypical images of mechanics or construction workers. In these preconceptions, they substituted a mechanic for a mechanical engineer. One girl was a "blank slate" with no idea of what an engineer was or did. The girls abandoned these naïve or non-existent preconceptions for authentic images of engineers after par- 
ticipation in STEM Club. For engineer drawings, the change in the engineer image gender was also greater than the change observed for scientist images. The number of post-test female engineer images showed a $42 \%$ increase from the pre-test compared to the $30 \%$ increase in female scientist images from the pre-test. The female scientist/ engineer ISE role model may have influenced the girls to replace male scientist or engineer images with female images. By contrast with the findings of Buck et al. (2002), the ISE retained her STEM practitioner identity. Unlike the female scientists in the Buck et al. (2002) study, she was not categorized as a teacher. The coordination relationship of the ISE-EST partnership allowed the ISE and EST to play distinct roles which were recognized as such by the students.

Likewise, this study's results, 1) broadening perceptions of scientists beyond the traditional male stereotype to include more females; 2) developing realistic perceptions of engineers involved in design and laboratory research, rather than as mechanics or construction workers; and 3) dramatically broadening perceptions of engineers to include more females, differ from the results of the HGGC project (Silver \& Rushton, 2008a; Silver \& Rushton, 2008b). In the present study, gifted fifth grade girls' perceptions of scientists and engineers became more realistic while those of the fifth graders who participated in the HGGC project became more stereotypical. These divergent outcomes suggested that a short (1 - 2 weeks) intensive building project, the HGGC electric car, reinforced scientist and engineer stereotypes. By contrast, the STEM Club that was created through an ISE-EST partnership dispelled scientist and engineer stereotypes. The synergistic relationship between the ISE and EST as distinguished from the visitor role played by the scientists and engineers in these earlier studies was critical to developing more realistic scientist and engineer images.

In their study of middle school students in grades 6 - 8, Fralick, Kearn, Thompson \& Lyons (2009) found that even these older students had limited understanding of engineers and their work. Middle school students either had "no perception of engineering" (Fralick et al., 2009: p. 60) or associated engineering with manual labor. Like the gifted fifth grade girls in this study, the middle school students had more developed images of scientists as experimenters and observers. The persistence of naïve engineer stereotypes into the middle school grades identified by Fralick et al. (2009) together with the indication from this study that gifted fifth grade girls who participated in a STEM Club developed realistic and sophisticated perceptions of engineers suggest that outreach efforts to introduce children to engineering should begin in elementary school.

\section{Suggestions for Future Work}

In this case study involved gifted fifth grade girls. Future work can address whether such ISE-EST partnerships can be effective in creating STEM Clubs for groups of male and female gifted students and for male and female students having a range of abilities. It would be valuable to examine if and how these groups of children have their perceptions of scientists and engineers affected by their participation in such STEM Clubs. 


\section{References}

Ashbrook, P. (2010). Inquiry at Play. Science and Children, 48, 26-27.

Bodzin, A., \& Gehringer, M. (2001). Breaking Science Stereotypes. Science and Children, 39, 3641.

Bohrmann, M. L., \& Akerson, V. L. (2001). A Teacher's Reflections on Her Actions to Improve Her Female Students' Self-Efficacy toward Science. Journal of Elementary Science Education, 13, 41-55. http://dx.doi.org/10.1007/BF03176219

Buck, G. A., Leslie-Pelecky, D., \& Kirby, S. K. (2002). Bringing Female Scientists into the Elementary Classroom: Confronting the Strength of Elementary Students' Stereotypical Images of Scientists. Journal of Elementary Science Education, 14, 1-10. http://dx.doi.org/10.1007/BF03173844

Carlisle, P. (2011). Scientists on a Mission. Science and Children, 48, 74-79.

Carlone, H. B., Hauen-Frank, J., \& Webb, A. (2011). Assessing Equity beyond Knowledge-and Skills-Based Outcomes: A Comparative Ethnography of Two Fourth Grade Reform-Based Science Classrooms. Journal of Research in Science Teaching, 48, 459-485.

http://dx.doi.org/10.1002/tea.20413

Chambers. D. W. (1983). Stereotypic Images of the Scientist: The Draw-A-Scientist-Test. Science Education, 67, 255-265. http://dx.doi.org/10.1002/sce.3730670213

Farland-Smith, D. (2012). Personal and Social Interactions between Young Girls and Scientists: Examining Critical Aspects for Identity Construction. Journal of Science Teacher Education, 23, 1-18. http://dx.doi.org/10.1007/s10972-011-9259-7

Farland-Smith, D., \& McComas, W. (2009). Teaching the Human Dimension of Science. Science and Children, 46, 48-51.

Finson, K. D., Beaver, J. B., \& Cramond, B. (1995). Development and Field Test of a Checklist for the Draw-A-Scientist Test. School Science and Mathematics, 95, 195-206.

http://dx.doi.org/10.1111/j.1949-8594.1995.tb15762.x

Fralick, B., Kearn, J., Thompson, S., \& Lyons, J. (2009). How Middle Schoolers Draw Engineers and Scientists. Journal of Science Education and Technology, 18, 60-73. http://dx.doi.org/10.1007/s10956-008-9133-3

Hodson, D. (2003). Time for Action: Science Education for an Alternative Future. International Journal of Science Education, 25, 645-670. http://dx.doi.org/10.1080/09500690305021

Hodson, D. (2004). Going beyond STS: Towards a Curriculum for Sociopolitical Action. The Science Education Review, 3, 2-7.

Joyce, B. A., \& Farenga, S. J. (1999). Informal Science Experience, Attitudes, Future Interest in Science, and Gender of High-Ability Students: An Exploratory Study. School Science and Mathematics, 99, 431-437. http://dx.doi.org/10.1111/j.1949-8594.1999.tb17505.x

Kaufman, E. E. (2010). Making a Difference for the Future. NSTA Reports, 22, 3.

Knight, M., \& Cunningham, C. (2004). Draw an Engineer Test (DAET): Development of a Tool to Investigate Students' Ideas about Engineers and Engineering. In E. Matson, \& S. Deloach (Eds.), Proceedings of the 2004 American Society for Engineering Education Annual Conference \& Exposition (pp. 2530-2540). Salt Lake City, UT: American Society for Engineering Education.

Leffler, B., \& Crauder, B. (2011). T’ was the Start of Science Notebooking. Science and Children, 49, 56-61.

Maltese. A. V., \& Tai, R. H. (2010). Eyeballs in the Fridge: Sources of Early Interest in Science. 
International Journal of Science Education, 32, 669-685.

http://dx.doi.org/10.1080/09500690902792385

Marek, E. A. (2009). Genesis and Evolution of the Learning Cycle. In W.-M. Roth, \& K. Tobin (Eds.), World of Science Education: Handbook of Research in North America (pp. 141-156). Rotterdam, Netherlands: Sense Publishers.

McCann, F., Marek, E. A., Pedersen, J., \& Falsarella, C. (2007). CLSI: Cool Life Science Investigations. Science and Children, 45, 26-29.

McCann, F., Millsap, K., Schmidt, S., \& Falsarella, C. (2010). Time for a Change. Science and Children, 47, 41-45.

McCann, F., Pedersen, J., Falsarella, C., \& McCann, P. (2008). There's More to Light than Meets the Eye. Science Scope, 31, 33-39.

McNeill, K. L. (2011). Elementary Students' Views of Explanation, Argumentation and Evidence, and Their Abilities to Construct Arguments over the School Year. Journal of Research in Science Teaching, 48, 793-823. http://dx.doi.org/10.1002/tea.20430

Melber, L. H. (2003). Partnerships in Science Learning: Museum Outreach and Elementary Gifted Education. Gifted Child Quarterly, 47, 251-258.

http://dx.doi.org/10.1177/001698620304700402

National Science Teachers Association. (2010). NSTA Reports, 21(7), 1-4.

National Science Teachers Association. (2011a). NSTA Reports, 22(6), 20-21.

National Science Teachers Association. (2011b). NSTA Reports, 23(4), 22-23.

O’Neill, T. B. (2010). Fostering Spaces of Student Ownership in Middle School Science. Equity \& Excellence in Education, 43, 6-20. http://dx.doi.org/10.1080/10665680903484909

Park, S., \& Oliver, J. S. (2009). The Translation of Teachers' Understanding of Gifted Students into Instructional Strategies for Teaching Science. Journal of Science Teacher Education, 20, 333-351. http://dx.doi.org/10.1007/s10972-009-9138-7

Patton, M. Q. (2002). Qualitative Research \& Evaluation Methods. Thousand Oaks, CA: Sage Publications.

Rawson, C. H., \& McCool, M. A. (2014). Just Like All the Other Humans? Analyzing Images of Scientists in Children's Trade Books. School Science and Mathematics, 114, 10-18.

http://dx.doi.org/10.1111/ssm.12046

Scantlebury, K., Tali, T., \& Rahm, J. (2007). FORUM: “That Don't Look Like Me.” Stereotypic Images of Science: Where Do They Come from and What Can We Do with Them? Cultural Studies of Science Education, 1, 545-558. http://dx.doi.org/10.1007/s11422-006-9023-z

Schibeci, R. A. (1986). Images of Science and Scientists and Science Education. Science Education, 70, 139-149. http://dx.doi.org/10.1002/sce.3730700208

Silver, A., \& Rushton, B. S. (2008a). The Effect of the Horsham Greenpower Goblin Challenge on Children's Attitudes towards Science, Engineering and Technology. Education, 36, 339-350.

Silver, A., \& Rushton, B. S. (2008b). Primary-School Children's Attitudes towards Science, Engineering and Technology and Their Images of Scientists and Engineers. Education, 36, 51-67.

Steinke, J., \& Long, M. (1996). A Lab of Her Own? Portrayals of Female Characters on Children's Educational Science Programs. Science Communication, 18, 91-115.

http://dx.doi.org/10.1177/1075547096018002001

Thompson, S., \& Lyons, J. (2008). Engineers in the Classroom: Their Influence on AfricanAmerican Students' Perceptions of Engineering. School Science and Mathematics, 108, 197210. http://dx.doi.org/10.1111/j.1949-8594.2008.tb17828.x 
Tucker-Raymond, E., Varelas, M., Pappas, C. C., Korzh, A., \& Wentland, A. (2007). “They Probably Aren't Named Rachel": Young Children's Scientist Identities as Emergent Multimodal Narratives. Cultural Studies of Science Education, 1, 559-592.

http://dx.doi.org/10.1007/s11422-006-9017-x

Vanmali, B. H., \& Abell, S. K. (2009). Finding a Place for Girls in Science. Science and Children, $46,62-63$

Walls, L. (2012). Third Grade African American Students' Views of the Nature of Science. Journal of Research in Science Teaching, 49, 1-37. http://dx.doi.org/10.1002/tea.20450

Weiland, I. S., \& Akerson, V. L. (2013). Toward Understanding the Nature of a Partnership between an Elementary Classroom Teacher and Informal Science Educator. Journal of Science Teacher Education, 24, 1333-1355. http://dx.doi.org/10.1007/s10972-013-9343-2

\section{Submit or recommend next manuscript to SCIRP and we will provide best service for you:}

Accepting pre-submission inquiries through Email, Facebook, LinkedIn, Twitter, etc.

A wide selection of journals (inclusive of 9 subjects, more than 200 journals)

Providing 24-hour high-quality service

User-friendly online submission system

Fair and swift peer-review system

Efficient typesetting and proofreading procedure

Display of the result of downloads and visits, as well as the number of cited articles

Maximum dissemination of your research work

Submit your manuscript at: http://papersubmission.scirp.org/

Or contact ce@scirp.org 